Richman, N., Douglas J., Hunt, H., Lansdown, R., \& Levere, R. (1985). Behavioural methods in the treatment of sleep disorders - a pilot study. Journal of Child Psychology and Psychiatry, 26, 581-590.

Richman, N., Stevenson, J. E., \& Graham, P. J. (1975). Prevalence of behaviour problems in three year old children: An epidemiological study in a London Borough. Journal of Child Psychology and Psychiatry, 16, 277-287.

Sanders, M. R., Bor, B., \& Dadds, M. (1984). Modifying bedtime disruptions in children using stimulus control and contingency management techniques. Behavioural Psychotherapy, 12, 130141.

Seymour, F. W., Bayfield, G., Brock, P., \& During, M. (1983). Management of night waking in young children. Australian Journal of Family Therapy; 4, 217-222.
Seymour, F. W., Brock, P., During, M., \& Poole, G. (1983). Management of night waking in young children. Paper presented at New Zealand Psychological Conference, Auckland.

Thomas, A., Chess, S., \& Birch, H. G. (1968). Temperament and Behaviour Disorders in Children. N.Y.: N.Y. University Press.

Thomas, E. P. (1982) Night waking in preschool children: An assessment and intervention. Unpublished Masters Thesis, University of Waikato, New Zealand.

Thornton, P., Walsh, J., Webster, J., \& Harris, C. (1984). The Sleep Clinic. Nursing Times, 4043.

Werry, J. S., \& Carlielle, J. (1981). Common sleep problems in children under five. Unpublished manuscript, Department of Psychiatry, University of Auckland.

\title{
Obituary to Robin Winkler
}

It is with great sadness that I inform ABMA members of the death of Robin Winkler on 26th November, 1986 in Perth. While Robin was well known to members of the association, many may not be aware of his struggle with cancer over the last few years. Those who were in contact with Robin during this period were deeply affected by the courage and determination with which he faced his illness. Some of us were privileged to witness an example of this spirit when Robin presented an invited paper on the history of behaviour modification in Australia at the ABMA conference in Sydney last year.

Robin's achievements were both personal and international. He has had a great and lasting impact on many individuals, particularly his students at the Universities of New South Wales and Western Australia. Robin's international contribution to psychology was marked by originality of thought and concern for humanitarian values. He frequently took risks in his challenging of conventional wisdom. His research activities were extremely broad, and included innovative work on the interrelations between psychology and economics, the application of psychology to the provision of health care, and the social psychology of torture, just to name a few. In his teaching and research, Robin has made an outstanding contribution to the development of behaviour modification in Australia.

Robin's death is a great loss to psychology and to the academic community as a whole. The untimely death of a person of such special personal qualities and distinctive intellectual and creative ability is a moment of great sorrow. There is no doubt that the influence of his work and the personal inspiration which he provided to his students and colleagues will continue to affect many of us in the years ahead. We will miss him deeply. We all join in extending our sympathy to his wife, Anne, and his children, Nicole and Christopher. 